p. 414

\section{軍人とスポーツ (そのI)}

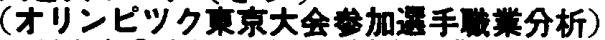

研究者○大沢 英雄, 橋本 豊司, 十枝内 功

\section{一人とスポーツ”栱 1)}

我々は普通，新聞，ラジオ，テレビ等を見，或は聞い た時に，軍人選手が，あらゆるスポーツに活躍している 事が目につくと思5.

オリンピツク東京大会に於ても軍人選手の活踓が多 く，又日本に於て自衛泍体育学校を設立し，強化対策々 した点からして軍人とスポーツとはどんな関係があるか を調べて見たいと思います。

昔, 軍人の体力造りにスボーッを利用している事が非 嫦に多いと云われている。

ローマ時代に於て子軍人の訓練の中に数多くスポーツを 取り入れ，戦闘に於てむ奻果を表わした様に思われる.

中世期に於て 8騎士道の訓練に用いられてきたし近代 に於て子軍人の訓練に数多くの、スポーツ的要素を持つ た訓練が行なわれる事を見て，軍人とスポーツとは深い 関係がある様に思われる。

しかし、スポーツが必ずしす軍人訓綀にばかり，使わ れていたかといらとそらではなく，古代から現代にかけ て，レクリエーションとして，又，見せ物としてるあつ
たと思われる。

しかし，今回は，軍人とスポーツに関して，近代に於 て各スポーツ大会に，軍人選手がいかに活躍しているか と云う事を見る為，その一つとして，世界のスポーツの 発典と云われるオリンピック夫会。

其の 1 として昨年我国に，於て行なわれたオリンピッ ク東京大会に打ける軍人選手と，その他の虺手の参加数 を\%テージで表わして見たいと思います。

むちろん，これからオリンピックローマ大会メルボル ン大会と，前に逆昇つて行きたいと思ら。

調查の対象は，オリンピツク東京大会参加の男子だけ とし，名前のわかつた者 2170 名，その5ち職業のわか つた者 963 名 $41.5 \%$.

以上の結果から見て，オリンピツク東京大会で，総合 第1这から第3位になつたアメリカ, ソ連, 日本を例 に取りますと，アメリカに於ては，学生が非常に多く $53 \%$ ，続いて $24.6 \%$ の軍人， $69 \%$ の会社員 となつてい

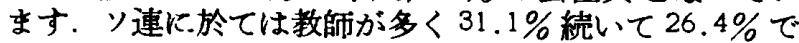
学生，軍人は $20.8 \%$ で三番目です．日本は会社員が多 く $47.3 \%$, 続いて $36.8 \%$ の学生，次に6.9\%で軍人.

調查した，参加国の平均を見ますと $39.3 \%$ で学生 $19.4 \%$ 会社員 $14.2 \%$ で軍人となつています

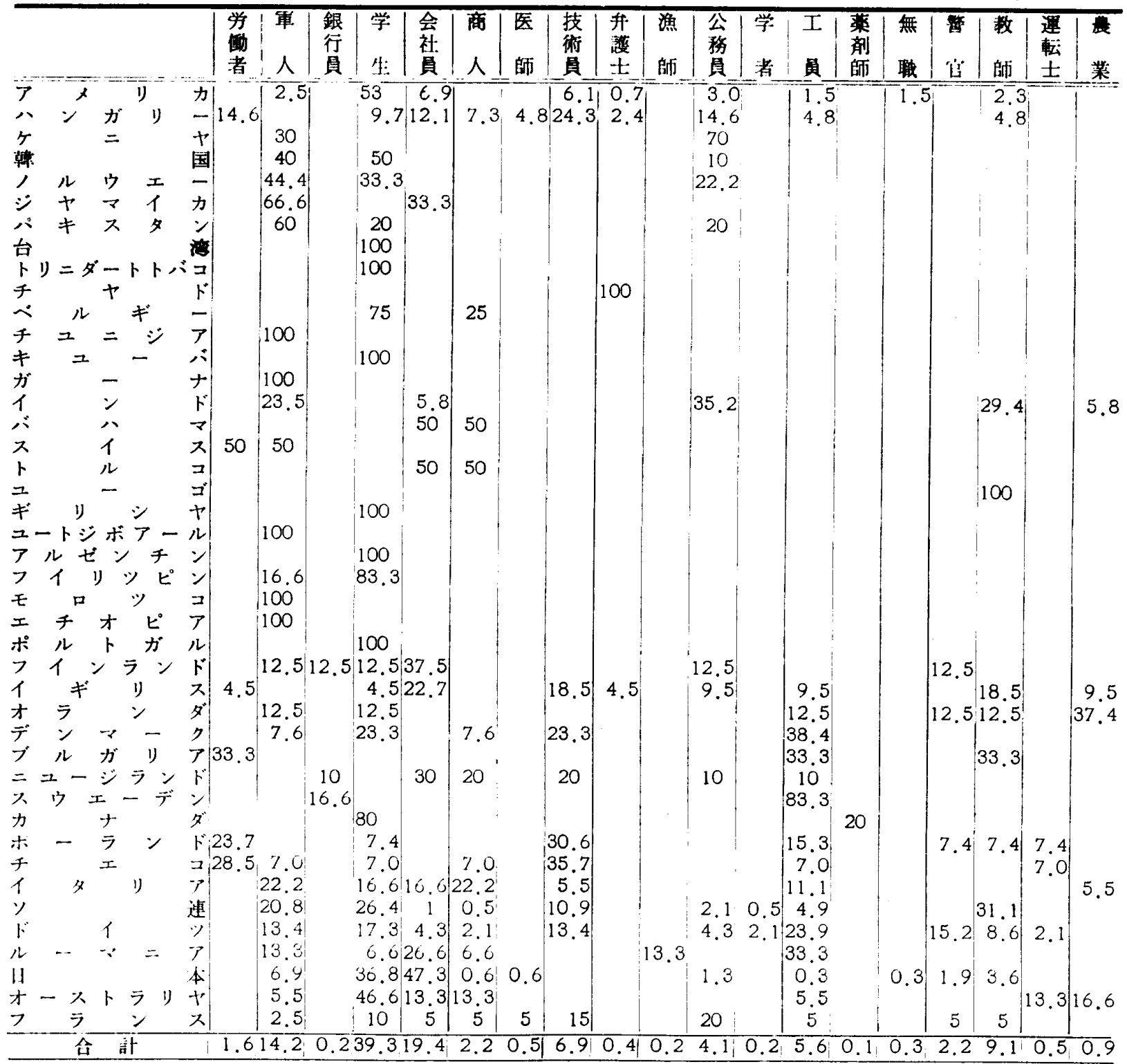

以上の様に参加数も非常に多く，又好成績が目に入る と思います。連続 2 回優勝のアペべにろ，日本の円 谷，三宅その他侵秀な成績を残した選手が沢山います。 もちろん強くなつてから軍人になつたと思われる人むい
ますが，しかし軍人の規律, 訓練の中に，スポーツに適 するなんらかの性格が含まれているのではないだろらか と云ら事で調査を進めてみました. 今後も軍人とスポー ツに関して，更に研究を㳭めて行きたいと思います。 